\title{
Integrating design thinking into instructional design: The \#OpenTeach case study
}

\author{
Caitríona Ní Shé \\ Trinity College Dublin \\ Orna Farrell, James Brunton, Eamon Costello \\ Dublin City University
}

\begin{abstract}
Online education is becoming the norm in higher education. Effective instructional design methods are required to ensure that "ever-connected" students' needs are being met. One potential method is design thinking: an agile methodology that stresses the importance of empathy with the student. The \#OpenTeach fully online course was designed using design thinking principles and delivered in Spring 2020. This article reports on a case study which focused on the use of design thinking to design and develop the \#OpenTeach course. The five iterative stages of design thinking (empathy, define, ideate, prototype and test) were integrated into the design and development of the course materials. The findings of this study indicate that the use of the design thinking process may be used by instructional designers to achieve empathy with their learners, which will ensure learners successfully engage and achieve the learning objectives of the course.
\end{abstract}

Implications for practice or policy:

- A rich case study of the successful integration of design thinking within the instructional design methodology of an online teacher education project is valuable to educationalists who wish to follow a user-centred empathetic approach.

- Instructional designers should focus on empathising with their student cohort to successfully engage students in the content that has been designed, and developed, as part of an online course.

Keywords: online teaching, instructional design, design thinking, persona, empathy maps

\section{Introduction}

Synergies exist between instructional design (ID) and design thinking, although it is not yet clear how, and to what effect, design thinking can be used in the development of instructional materials. While there is considerable awareness of how ID models can be used in higher education (HE), more evidence relating to the use of design thinking as part of the instructional design process is needed (Christensen \& West, 2017; Matthews et al., 2017; Svihla, 2017). The application of design thinking to ID in HE courses has the potential to create more authentic and empathetic learning experiences for students thus fostering student engagement (Kahu, 2013). This article reports on a case study which explored how the design thinking process facilitated the design and development of a short professional development (PD) course on how to teach online: the \#OpenTeach course. The main contribution of this work is in the detailed description of the integration of design thinking in the ID process.

We (the \#OpenTeach project team) were based in the Open Education Unit (OEU) of Dublin City University (DCU). The OEU has had a long remit in widening access to education through online learning. The OEU employs part-time online educators to provide academic support to students. The objective of the \#OpenTeach project was to develop a research-informed online PD course for online educators, specifically the OEU online educators (https://openteach.ie/home/). This phased project stipulated that the course and its instructional materials were developed iteratively, with pilot workshops, before the final course delivery in March 2020. While there are many ID models available it is important to select a model suited to the creative design process in the specific learning situation (Branch \& Kopcha, 2014). This project used design thinking as it supports a focus on user needs - a key requirement of the \#OpenTeach project.

This article has five sections. The first section provides a review of relevant literature, concluding with the research questions. The second section outlines the methodology. The third section describes the implementation of the design thinking process. The fourth section contains an analysis of the data from the 
first workshop. The final section draws together the research outputs and discusses the value of the design thinking process as experienced by the \#OpenTeach team and recommendations for future work.

\section{Contexts from the literature}

This section presents contexts from the literature about ID, design thinking and the intersection of these approaches in the HE context.

ID is defined as the "translating principles of learning and instruction into plans for instructional materials, activities, information resources, and evaluation" (Smith \& Ragan, 2005, p. 2). ID as an approach to designing and developing learning experiences dates back to the Second World War and has long been recognised as critical to the enactment of quality teaching and learning in HE (Conole, 2013; Dimitriadis \& Goodyear, 2013; Laurillard, 2012). ID has since evolved with many different models now in existence, the most referenced being the analyse, design, develop, implement, evaluate (ADDIE) model (Adnan \& Ritzhaupt, 2018; Branch \& Kopcha, 2014; Göksu et al., 2017; Svihla, 2017).

However, instructional designers have been moving away from traditional models such as ADDIE because "design is no longer just concerned with content, or a single technological learning artefact, but with learning environments" (Wasson \& Kirschner, 2020, p. 827). A further criticism of traditional ID models is that they are too slow and inflexible due to waterfall or linear design stages which must be completed step by step and focus too much on content and not enough on student-educator interaction (Bates, 2019; Shivla, 2017). Therefore, the focus of design has moved from content creation to learning experience, an emphasis on speed, flexibility and non-linear processes. This shift in thinking and approach draws on ideas from disciplines such as product development and software design (Adnan \& Ritzhaupt, 2018; Wasson \& Kirschner, 2020). As agile (iterative, flexible and adaptable) and user-centred methods were developed for software development, so too were they imported into ID, bringing a focus on the user or student experience of interacting with the interface or learning environment (Adnan \& Ritzhaupt, 2018; Tawfik et al., 2021). For example, design thinking, an agile user-centred approach, has begun to be applied in the field of ID.

Design thinking can be a mindset, a process and a toolkit for approaching problem-solving (Brenner et al., 2016; Dam \& Siang, 2020a). Stefaniak (2020, p. 201) defines design thinking as "a process that embodies empathetic design of solutions and iterations of ideation and innovation while engaging in problemsolving". The design thinking approach originates from the Stanford Design School and was brought to the fore by the design company IDEO (Dam \& Siang, 2020b). The design thinking process encompasses a 5stage non-linear process: empathise, define, ideate, prototype and test (Dam \& Siang, 2020a) (Table 1).

Table 1

The five stages of the design thinking process

\begin{tabular}{|c|c|c|}
\hline Stage & Aim & Actions \\
\hline Empathise & $\begin{array}{l}\text { The first stage in the design thinking process } \\
\text { is to emphasise with the potential user and } \\
\text { understand their problems. }\end{array}$ & $\begin{array}{l}\text { Develop empathy maps about users } \\
\text { using research such as observations, } \\
\text { interviews, surveys and by engaging } \\
\text { stakeholders. }\end{array}$ \\
\hline Define & $\begin{array}{l}\text { The second stage of design thinking is to } \\
\text { consolidate the information obtained during } \\
\text { the empathise stage in order to define the } \\
\text { problem and establish features and functions } \\
\text { that will help solve the problem. }\end{array}$ & $\begin{array}{l}\text { Combine all your research and observe } \\
\text { where your users' problems exist. }\end{array}$ \\
\hline Ideate & $\begin{array}{l}\text { The third stage is the design thinking process } \\
\text { is to ideate or develop ideas on how to } \\
\text { creatively solve the problem. }\end{array}$ & Brainstorm ideas on users' unmet needs. \\
\hline Prototype & $\begin{array}{l}\text { Developing a draft or prototype version of the } \\
\text { final solution is the fourth stage in design } \\
\text { thinking. }\end{array}$ & $\begin{array}{l}\text { Develop a rough physical prototype of } \\
\text { your solution. }\end{array}$ \\
\hline Test & $\begin{array}{l}\text { The final stage of the design thinking process } \\
\text { is testing. This stage involves redefining and } \\
\text { empathising with the end user to ensure the } \\
\text { best solution is sought. }\end{array}$ & $\begin{array}{l}\text { Ask users for feedback on protype, } \\
\text { incorporate feedback and iterate } \\
\text { prototype. }\end{array}$ \\
\hline
\end{tabular}


Design thinking has been applied in many contexts such as HE, healthcare, computing and the car industry, to develop human-centred solutions to complex problems (Brenner et al., 2016). In HE, design thinking has been used to improve student experience and to teach design thinking to students in disciplines such as engineering, science and architecture (Luka, 2014; Morris \& Warman, 2015). Design thinking has been found to improve outcomes in many contexts as it can lead to innovative human-centred solutions which are more inclusive (Liedtka, 2017; Svihla, 2017).

In the ID context, the introduction of design thinking is part of the increasing shift towards more agile and user-centred approaches. According to Svihla (2017), the design thinking process is reflective of the iterative practices and inherent sensibilities of experienced instructional designers and is therefore sometimes implicit in an instructional designer's work. The iterative approach to problem-solving inherent in design thinking aligns with a systematic approach to ID (Stefaniak, 2020).

Design thinking shares similarities with other agile instruction design approaches, such as the successive approximation model (known as SAM), which also include the user and stakeholders in the design process (Svihla, 2017). Further similarities are evident in Stefaniak's (2020) mapping of design thinking stages to ID steps. For example, the empathise stage is similar to persona development and learner analysis, the prototyping stage is similar to rapid prototyping and finally the test stage is similar to usability testing.

However, the key difference between design thinking and other instructional design models is the emphasis on human-centred design and in particular empathising with students or end users and seeing them as a person rather than an input (Stefaniak, 2020). Empathic design practices are at the core of design thinking and ensure that the design process remains focused on the student experience. Thus, the use of the design thinking process, as documented in this article, may be used by instructional designers to overcome some of the barriers that have been identified in successfully empathising with learners (Matthews et al., 2017).

In order to ensure that course materials meet the needs of the "ever-connected" technology-equipped student, ID models need to be reconsidered (Conole, 2013; Goodyear, 2015; Laurillard, 2012; Svihla, 2017; Wasson \& Kirschner, 2020). In addition, there is a requirement to map out the processes involved in designing for learning and to examine the theoretical underpinnings of such processes (Christensen \& West, 2017; Dimitriadis \& Goodyear, 2013). We incorporated a design thinking approach in the ID process for the \#OpenTeach course to address the needs of our intended course participants, as empathising with the user was a key objective. This study investigated the use of design thinking in the ID process with the aim of improving student experience in the \#OpenTeach course. In order to address these issues, the following research questions were formulated:

(1) How was design thinking integrated into the ID of the \#OpenTeach course?

(2) What was the effect of the design thinking process on the user experiences in the first pilot workshop of the course?

\section{Methodology}

We selected a case study methodology to frame this research. Case study research is useful for providing a detailed descriptions of how design thinking was implemented in the design of the course and how the participants reacted to the key features of the course. This approach builds knowledge and insight in order to inform professional practice (Stake, 1995; Yin, 2003). The research questions posed in this study will inform ID practice. This study adopted a single intrinsic case study approach, as the design thinking process constitutes a single case, with intrinsic value, that requires a documented description (Stake, 1995). Using multiple sources of data, this approach facilitated a rich narrative of the design thinking process. By understanding the design thinking process in this exemplary case, practical knowledge is generated that applies to the practice of ID (Stake, 1995).

This case study focused on the use of design thinking in the ID of a course; thus, the approach to designing and developing the course was integral to the research. Figure 1 outlines the steps involved in developing the \#OpenTeach course. 


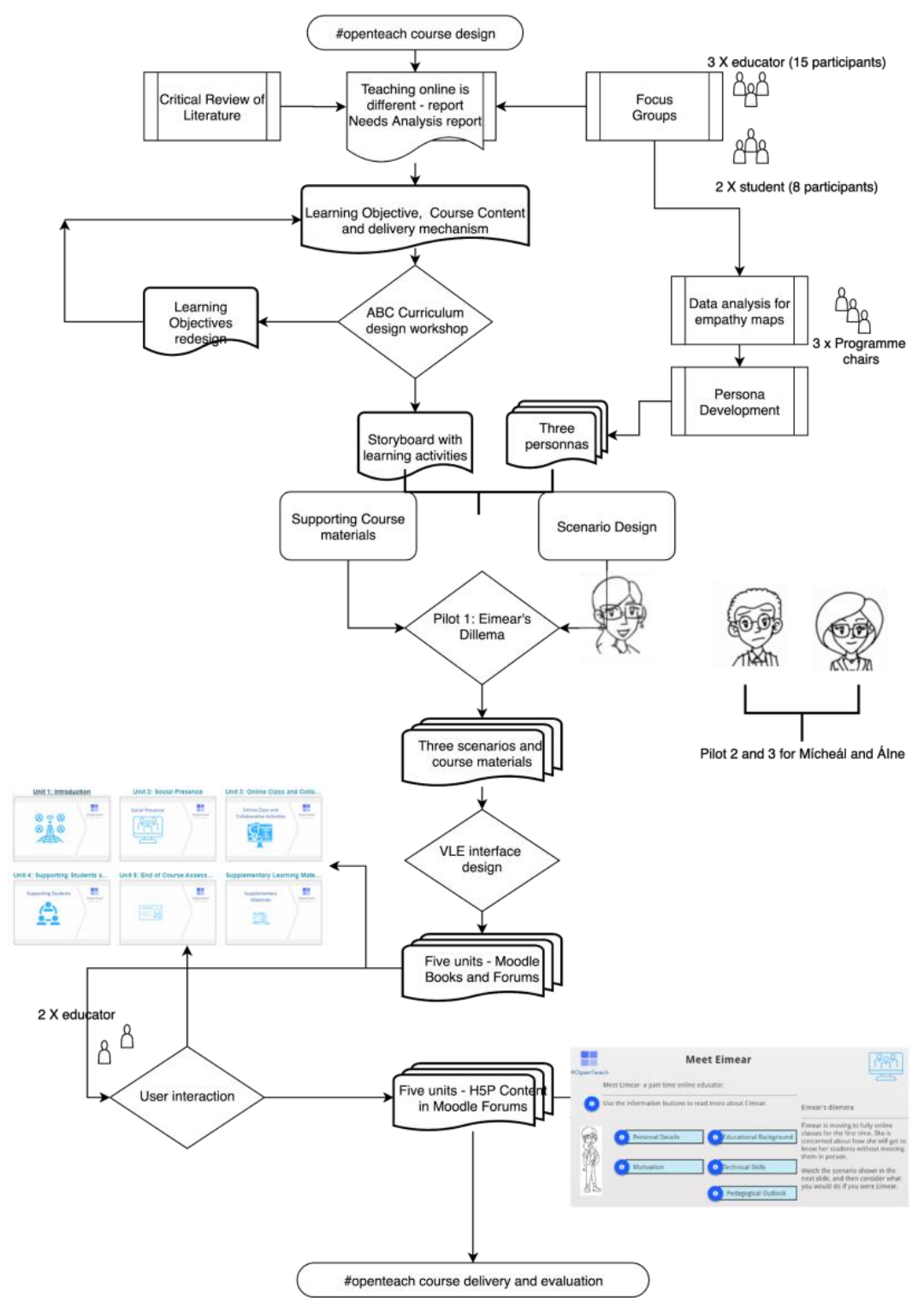

Figure 1. Steps involved in the design of the course and the associated research

A literature review was carried out to identify best practice in online teaching and the PD needs of online educators (Ní Shé et al., 2019). Surveys and focus groups were conducted to determine the specific needs of the OEU online educators and their students (Farrell et al., 2019). The subsequent course design and development had several steps. Firstly, the course learning objectives, content and delivery mechanism were defined. The following course topics were identified: social presence, online class and collaborative activities, student supports and discussion forums. Secondly, the arena, blended, connected (ABC) curriculum design process was used to draft a curriculum (Laurillard, 2012; Young \& Perović, 2016). Further information on this element of the course design is contained in the ABC blog (Ní Shé et al., 2020). The next step was the ID and development of the course. A decision was taken to use scenario-based learning, with one scenario per course topic. A key feature of scenario-based learning is the posing of dilemmas. Scenarios were fleshed out using empathy maps and personas. Empathy maps, based on target user research data, are used to visually represent knowledge about users (Gibbons, 2018). Personas are fictional characters that designers create to represent real characteristics of their target users (Dam \& Siang, 2020c; Harley, 2015). Course materials, including videos for the scenarios and documents that facilitated the resolving of the dilemmas, were produced. Each scenario was piloted in at least one workshop, and the course materials were subsequently modified before the course was made available on the DCU Moodle platform. The case study presented in this article analysed the design thinking process up to the first pilot workshop carried out on Eimear's dilemma. The stages of the design thinking process, as explained in 
Table 1, were embedded in each design step: the personas, scenarios, course materials, workshops and final Moodle module were developed according to the aims and actions of each stage. The design thinking stages for the personas and scenarios are illustrated in detail below.

Data was gathered from multiple sources throughout the project. Interviews, surveys, observations, meeting notes and shared Excel spreadsheets were used. Table 2 lists the data gathered during each activity, the number and participant selection method and how it was used as part of the design thinking process.

Table 2

Details of data gathered for the design thinking process

\begin{tabular}{llll}
\hline Activity & Research data gathered & $\begin{array}{l}\text { No. and selection of } \\
\text { participants }\end{array}$ & Used for \\
\hline $\begin{array}{lll}\text { (a) OEU online } \\
\text { educator survey }\end{array}$ & $\begin{array}{l}\text { Survey data gathered in } \\
\text { Qualtrics and analysed }\end{array}$ & $\begin{array}{l}\text { All 120 DCU educators } \\
\text { were asked to complete the }\end{array}$ & $\begin{array}{l}\text { Course design } \\
\text { (including lear }\end{array}$ \\
& in Excel. & survey. $(n=55)$ & $\begin{array}{l}\text { objectives, sce } \\
\text { fund }\end{array}$
\end{tabular}

Used for in Excel.

(including learning objectives, scenarios for dilemmas, course materials), empathy maps, personas and virtual learning environment prototype development.

(b) OEU online educator focus groups

\section{(c) OEU}

programme team meetings

(d) ABC curriculum design process

\section{Draft curriculum and blog on the process.}

(e) Workshops (3 were held, the one on January 23 is examined in this article).
Response sheets to dilemma.

Evaluation sheets of pilot materials. Researchers' notes.
Meeting notes and excel spreadsheets

Online video interviews. Transcribed and then analysed in NVivo.

Purposeful sampling based on their longevity as an educator and their expertise. This ensured a representation of the body of online educators. $(n=$ 150

There are three programme teams within the (Uni dept.) of (University name). A meeting was held with each team.

1 workshop.

All \#OpenTeach project team members attended.
Workshops were advertised using the normal channels to ensure all educators in higher education institutions in Ireland had the opportunity to attend. Three workshops, one per dilemma. All participants at the workshops were asked to complete an evaluation sheet. $(N=29$ evaluation sheets for Eimear dilemma)
Profile the OEU online educators' persona development.

Curriculum alignment with learning objectives, learning activities and associated learning types.

Decision on use of scenario-based learning.

Pilot scenarios and dilemmas prototypes and make modifications, verify empathy maps 
Workshops were used as the testing ground for the course materials that had been developed. Participants were drawn from the wider online educator community, beyond DCU. At the end of each workshop, participants were asked to complete an evaluation form, targeted at establishing the effectiveness of the design thinking process in four areas: (a) the persona and scenario, (b) the course materials, (c) learning achieved and (d) possible improvements. The data was analysed using a directed content analysis. This deductive technique is appropriate when the structure of the analysis is operationalised based on prior knowledge or theory or when existing data is tested in a new context (Elo \& Kyngäs, 2008, p. 111). Quality was assured by adopting Silverman's (1993) approach to triangulation - an approach to capturing multiple truths about a topic via data using different sources, different modes of data collection and a team of researchers to collect and analyse the data. In this study, data was triangulated through the use of multiple data-gathering methods: survey, focus groups, design observational data, workshop response sheets and detailed literature reviews from participants. We reviewed the data extracts, analysis and findings.

Ethical approval for the study was granted by the DCU Research Ethics Committee (Reference: REC/2019/072). All participants were fully briefed, and informed consent was given. As participants were adults involved in education, it was deemed a minimal risk study.

\section{Implementation of the design thinking process}

In order to facilitate the transfer of a design thinking experience to similar contexts, the practical application of the process and how it encourages empathy and creativity is described in the following sections. An overview of the design thinking process, as used in this project, is described in the first section. This is followed by details of the steps required to develop personas and scenarios. The final section describes the workshop process that was used to test the course materials. This section constitutes the response to the first research question.

\section{Process overview}

We chose to use the Interactive Design Foundation's design methodology as it takes a pragmatic approach to implementing design thinking and is relatively straightforward (Dam \& Siang, 2020a). The steps taken to incorporate the five stages of design thinking in the course development are illustrated in Figure 2.

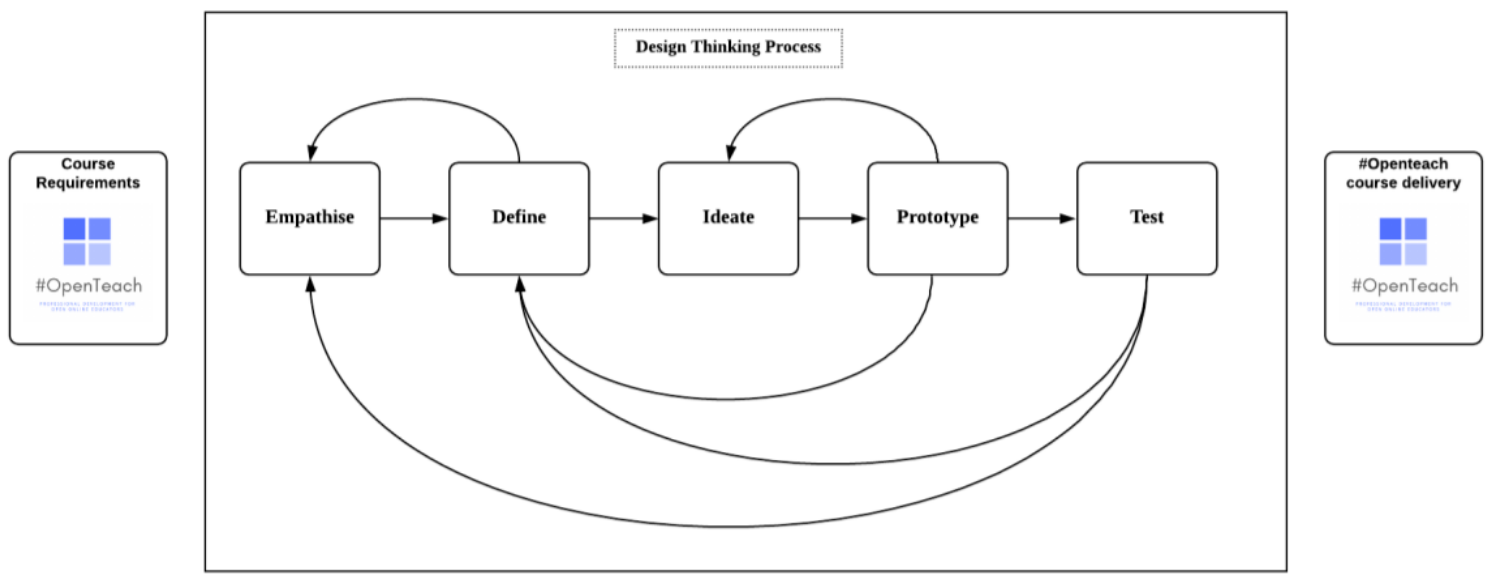

Figure 2. Design thinking for the \#OpenTeach course, based on Dam and Siang's (2020a) design methodology

Course requirements

The course requirements were gathered using the instruments below, as listed in Table 2:

(a) OEU online educator survey

(b) OEU online educator focus groups

(c) OEU programme team meetings

(d) ABC curriculum design process (Laurillard, 2012; Young \& Perović, 2016). 


\section{Empathise}

The first stage in the design thinking process is to empathise with the potential user and understand their problems (Dam \& Siang, 2020a). The process of empathising with the end user, in this case the online educators who would attend the \#OpenTeach course, was iterative. The creation of empathy maps was key to ensuring subsequent development of the course materials, such as the personas and scenarios, and was embedded in the design thinking process. As course material was prepared and evaluated, we repeatedly returned to this empathy stage.

Define

The second stage is to consolidate the information obtained during the empathise stage to define the problem and establish features and functions that will help solve this problem (Dam \& Siang, 2020a). During this stage, the personas, scenarios and course materials were defined and then redefined as feedback was obtained during subsequent stages of the process.

Ideate

The third stage is to ideate about how to creatively solve the problem (Dam \& Siang, 2020a). For example, several options for scenario creation were discussed; real-life recorded scenarios as well as animated versions were considered. We chose an animated scenario style after evaluating the various options.

\section{Prototype}

Developing a prototype version of the final solution is the fourth stage in design thinking (Dam \& Siang, 2020a). In the development of the \#OpenTeach course, this stage involved the production of a draft storyboard of each scenario and the course materials that were used to support the solving of the scenarios' dilemmas. These prototypes were modified after the feedback provided during the test stage.

Test

The final stage is testing (Dam \& Siang, 2020a). This stage involves redefining and empathising with the end user to ensure the best solution is sought. The workshops provided the \#OpenTeach team with the opportunity to test each of the scenarios and course materials. After the workshops, the scenarios and course materials were redefined to ensure that empathy with the end user had been achieved.

Course delivery

The fully online course was delivered during March 2020 using the DCU Moodle platform. There were 423 participants registered, and 160 completed the course assessment and received an associated digital badge ( $40 \%$ completion rate). The course delivery does not form part of the research reported in this article.

In order to further understand the integration of design thinking, the next two sections outline how the process was used in persona and scenario development.

\section{Persona development: Empathise and define}

Persona development was an iterative process that involved the empathise and define stages of the design thinking process. Figure 3 shows the steps involved.

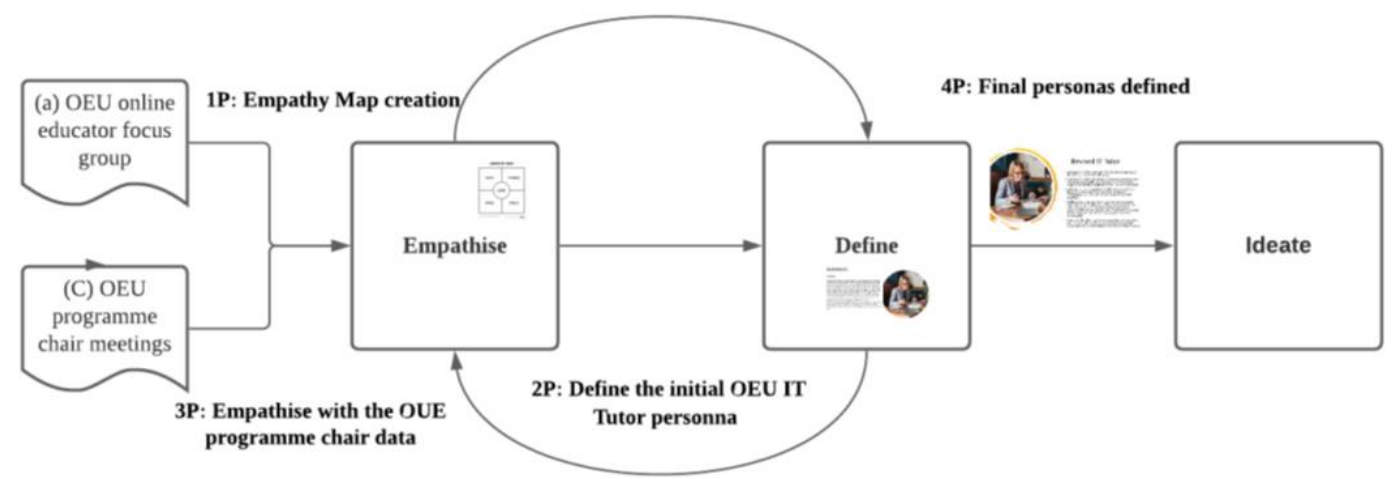

Figure 3. Empathise and define stages used in developing the personas. Each step is numbered with the letter " $\mathrm{P}$ ", to denote it is a step in the persona development process. 
Step 1P: Empathy map creation

Empathy maps were created using the data gathered during the initial online educator survey and focus groups (see (a) \& (b) in Table 2).

The data was categorised into two overarching categories, which represented the user characteristics required for the development of the course, the OEU online educators:

(1) perceptions of online teaching

(2) requirements for PD.

The data was then used to create two types of empathy maps that reflected this categorisation of the characteristics of the online educators. The Nielsen Norman group (Gibbons, 2018) empathy map format was used as it facilitated the articulation of an in-depth understanding of the different online educators. Gibbons (2018) specified that user data should be considered under four quadrants:

- Says: This contains segments of the actual conversations.

- $\quad$ Thinks: The researcher must make a judgement on what the user means by what they are saying; perhaps, there is some underlying or hidden thoughts about the user values that can be construed.

- Does: What the user does refers to the actions that the user has taken as articulated in their interview.

- Feels: The fourth quadrant contains the emotional state of the user as determined by the researcher.

Segments of the online educators' transcribed interviews were labelled "Says", and researcher insight was used to interpret what the users thought based on the overall interview. For example, several of the educators referred to difficulties they encountered when starting to teach online, or when moving from faceto-face to online teaching. The segments "so it was very difficult for me at the beginning" and "for the first two years I felt quite isolated" were labelled "Says". The analysis of relevant sections of the interview transcripts revealed that users think online classes are hard, particularly at the beginning, and that technology can be problematic and isolating. Thus, these were labelled "Thinks". One way that online educators overcome these difficulties is by preparing slides; another is to test out the technology. These difficulties were labelled "Does". Also, the emotions associated with these difficulties were worry and isolation, and they were labelled "Feels".

Figures 4 and 5 show sections of the empathy map created for perceptions of online teaching and requirements for PD. Please note that the entire empathy maps are too detailed to reproduce below.

\begin{tabular}{|c|c|}
\hline $\begin{array}{l}\text { "so it was very difficult for me at the beginning..." } \\
\text { "For the first two years I felt quite isolated. I wasn't } \\
\text { sure what I was doing, ... I found it (technology) } \\
\text { quite overwhelming when problems occurred" }\end{array}$ & $\begin{array}{l}\text { Online classes are hard, particularly, at the } \\
\text { beginning. } \\
\text { The technology can be problematic. } \\
\text { It can be isolating }\end{array}$ \\
\hline $\begin{array}{l}\text { "saying 'Hi' at the very beginning of the academic } \\
\text { year, like introducing yourself, ... kind of welcoming } \\
\text { the students ... like that they see you as a person like, } \\
\text { you know" }\end{array}$ & $\begin{array}{l}\text { Social presence is important, get it going right from } \\
\text { the start. } \\
\text { It helps with interaction, make sure the students think } \\
\text { of you as a person. }\end{array}$ \\
\hline $\begin{array}{l}\text { "like what I find the most difficult is the feedback, } \\
\text { because in face to face classes you can have an } \\
\text { instant feedback,... in online classes, you know when } \\
\text { somebody doesn't find it like engaging, the person } \\
\text { can just switch off" }\end{array}$ & $\begin{array}{l}\text { When students are not engaging in online class then } \\
\text { they are generally completely switched off. }\end{array}$ \\
\hline $\begin{array}{l}\text { "For me it means like being prepared. Having like a } \\
\text { set of slides prepared for the Students, quite detailed } \\
\text { slides." }\end{array}$ & Key to success is being prepared \\
\hline $\begin{array}{l}\text { FEELS } \\
\text { Isolated when starting out } \\
\text { Happy when interacting with students and when class } \\
\text { goes well } \\
\text { Confident } \text { When things work out } \\
\text { Worried } \text { Technology problems }\end{array}$ & $\begin{array}{l}\text { DOES } \\
\text { Prepares, for example slides } \\
\text { Aligns assignments and tutorials } \\
\text { Prompts students in discussion forums } \\
\text { Elicits information from students about their interests }\end{array}$ \\
\hline
\end{tabular}

Figure 4. Sections of the empathy map created from the data on online educators' teaching experiences 


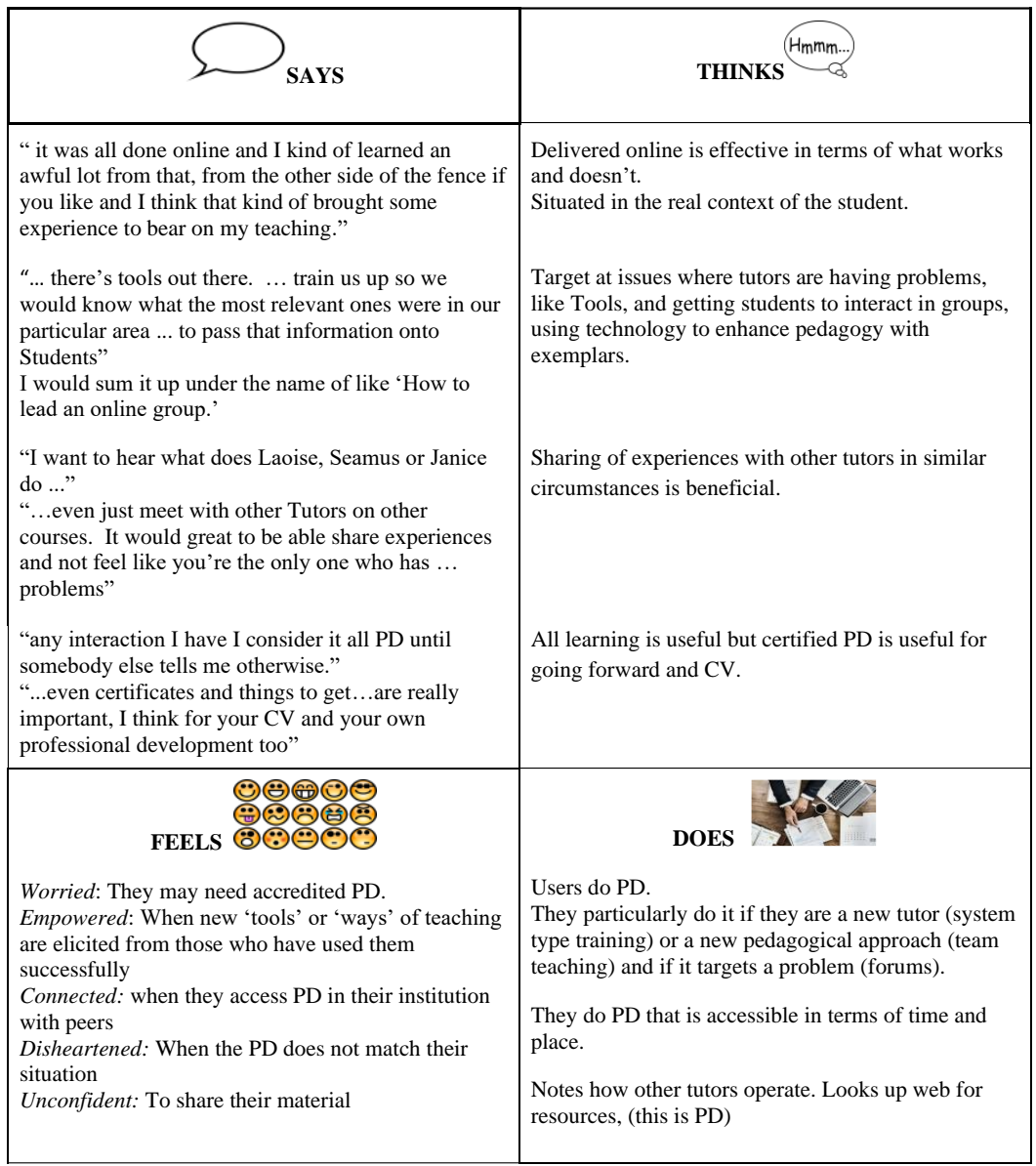

Figure 5. Subset of the empathy map created from the data gathered on online educator PD needs

Step 2P: Define the initial information technology online educator persona

An initial persona was defined using the empathy maps illustrated in Figures 4 and 5, the background data obtained from the initial survey [(a) in Table 2] and project team expertise. This persona was developed in line with the guidelines from the Nielsen Norman Group (Harley, 2015) and is illustrated in Figure 6.

\section{Persona IT Tutor 2}

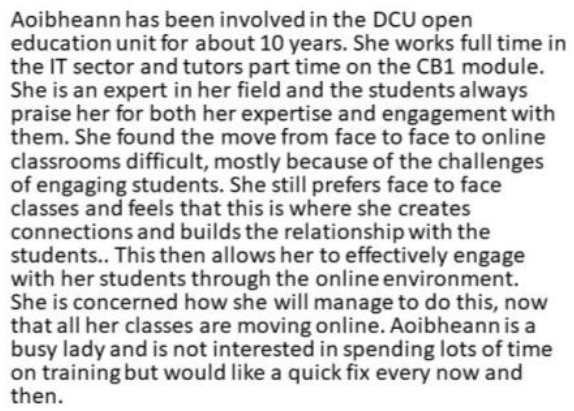

Figure 6. Aoibheann, an online educator persona

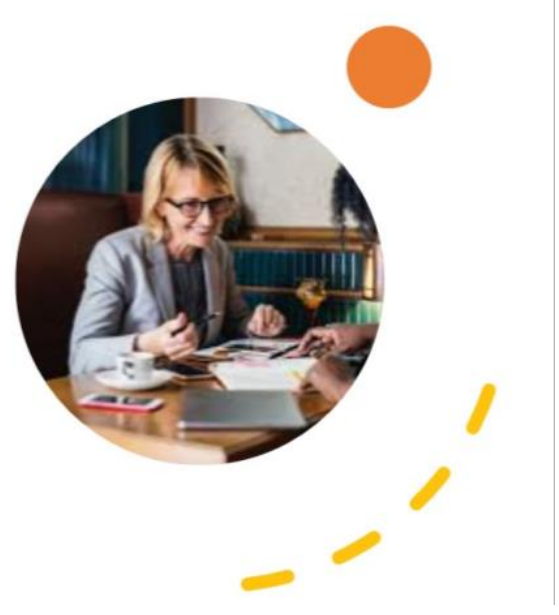

Step 3P: Empathise with the OEU Information Technology team data

This persona was circulated within the Information Technology team, and a meeting helped to further refine the persona [(c) in Table 2]. A spreadsheet containing the relevant characteristics of the online educators was created with the OEU programme team. A section of this anonymised data is shown in Figure 7. 


\begin{tabular}{|c|c|c|c|c|c|c|c|c|c|}
\hline Pseudonym & Gender & $T$ & Age & Current Other Work & How long in OEU & Completed Op & Education & Highest level & Part time stud: \\
\hline Lisa & Female & & $35-44$ & Fetac part time teaching & $>2$ years, $<5$ years & Did do Open ed & Masters in IT & & 9 Yes \\
\hline Mary & Female & & $35-44$ & ? & $>5$ years, $<10$ years & No & Full time & & 3 ? \\
\hline Sinead & Female & & $55-64$ & Lots of part time consultancy for University sector & $<3$ years & No & Degree in IMI/N & & B Possibly \\
\hline Aoibheann & Female & & $55-64$ & Teaching in University part time & 15 years + & Yes, Bsc & Masters & & 9 Yes \\
\hline Nora & Female & & $35-44$ & Teacher in Higher Education & $<3$ years & No & $P h D$ in IT & & Yes \\
\hline Roisin & Female & & $35-44$ & Working part time Community Service & $<2$ years & No & Post grad from D & & 9 Yes \\
\hline
\end{tabular}

Figure 7. Data relating to the Information Technology online educators. Persona details are highlighted in orange.

Step 4P: Final personas defined

The initial online educator persona was modified based on the data obtained from the Information Technology team. This modified persona was circulated to that team and revisions made before the final persona was agreed, as shown in Figure 8. Aspects that were changed included the fact that these online educators were familiar and comfortable with technology.

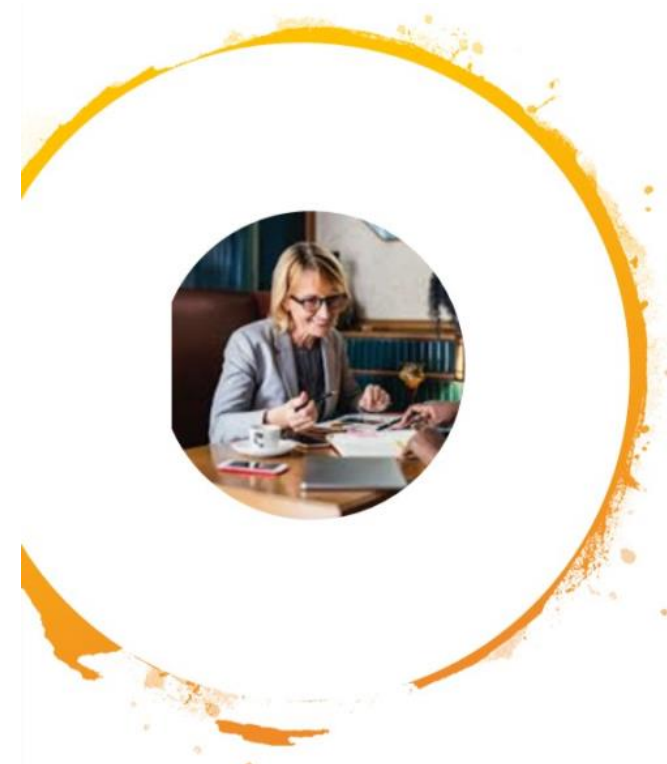

\section{Persona IT Tutor 2}

- Aoibheann is fifty years old. She has been tutoring in the OEU for more than 15 years.

- Aoibheann teaches in other institutions and does a bit of consultancy work also. She has a lot of teaching experience and has worked in the IT sector in the past.

- Aoibheann has attended some of the OEU modules herself and has a level 9 qualification. She has been involved in developing course materials for some of the OEU modules.

- While Aoibheann is an excellent tutor she has found the move from face to face to online challenging. All the move from face to face to online challenging. All completed an online course. She is well able to use the technology, it's the online class rapport she finds challenging.

- Aoibheann can be a bit stuck in her ways, but she has taken part in some face to face workshops. Being paid to attend professional development will be a requirement.

Figure 8. Revised persona: Aoibheann

For each of the three OEU programme teams (Information Technology, Humanities, and Postgraduate), two online educator personas were created. The programme teams considered that these personas were representative of the online educators employed by DCU. One of the team members remarked, "I feel like they actually work for us! I think they are very good characterisations of our online educator corps."

This Aoibheann persona, with a few amendments, became the Eimear character used in the social presence scenario developed for the course. The development of Eimear's dilemma is outlined in the next section.

\section{Scenario development: Define, ideate and prototype}

The development of the Eimear dilemma and associated scenario documents involved an iterative process using the define, ideate and prototype stages of the design thinking process. Figure 9 illustrates the steps involved. 


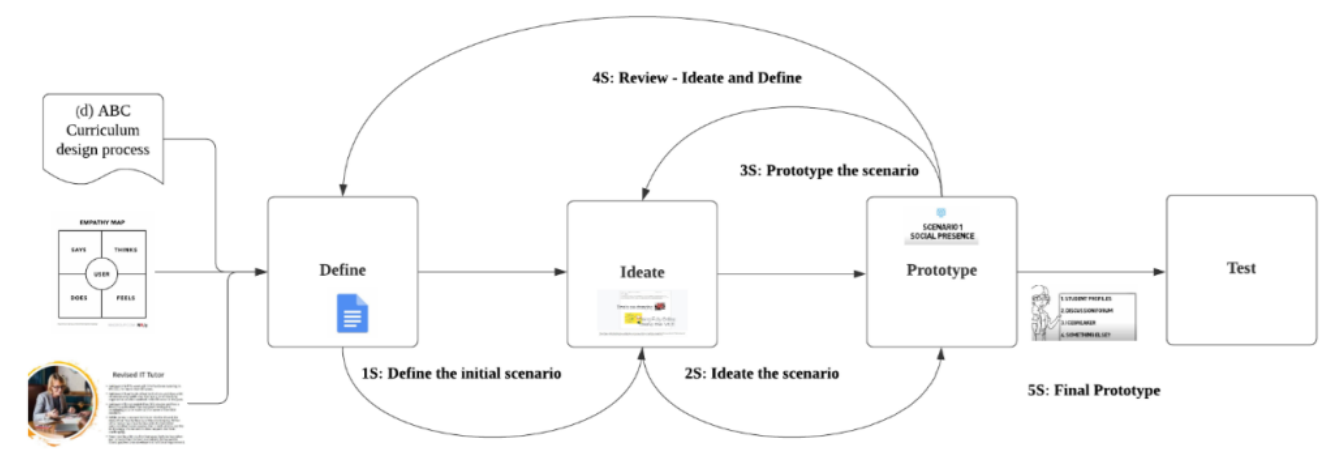

Figure 9. Define, ideate and prototype stages used in the development of the scenarios. Each step is numbered with the letter " $\mathrm{S}$ " denoting a step in the scenario development.

\section{Step 1S: Define the initial scenario}

The initial scenarios were defined using several elements of the design process, as indicated in Figure 9. The resultant output was a document that defined the story of the Eimear dilemma. The learning outcome for this scenario was based on how to start and maintain social presence. Figure 10 shows a draft of the story, which was circulated and agreed within the project team. Colour coding is applied to illustrate how the data was used to create the story. Sections in yellow were drawn from the persona in Figure 8 . Those in green were drawn from Figure 4 (the OEU educators' experiences with online teaching empathy map) and those in blue from Figure 5 (the PD needs empathy map).

\section{Eimear's Story - Setting the scene}

\section{Introduction}

$\mathrm{Hi}$, my name is Eimear.

I have been teaching on a distance degree programme for about three years. It is a part time job for me, I work as an IT specialist full time. I tutor because I really like the interaction with students and it is good for my CV in this ever changing working landscape.

It also pays!

This year things are changing, there will be no more face to face classes, I won't meet any of my 30 students in person. We are moving to fully online classes for the tutorials that I deliver.

Also we have been advised that all communication with students, bar personal matters, must be done using the university's Virtual Learning Environment.

\section{Last year my first communication with the students was face to face and I managed to get to know them and start a relationship with them which we maintained throughout the course using email, discussion forums and I supported them in both the face to face and online classes.}

I am a bit worried about this change to fully online. I am nervous about how I will get to know my students and
how I can support them without meeting them in person on campus. Last year I found it difficult to get the
students to get involved in the online classes, they didn't want to speak and I don't feel that confident using the
online classroom technology activities. Some students were nervous about posting questions on the discussion
forums, they preferred to email me or ask in person.

The course starts next week, and we have our first live online tutorial in two weeks. I would like to get some sense of my students and their backgrounds before the online class.

What should I do?

How do I go about getting the course started on the right foot? How can I start to build a relationship with my students onfine?

Figure 10. Eimear's story - 1st draft 
Step 2S: Ideate the scenario

Once the scenario was defined, a creative process was used to ideate the story. We investigated different methods of developing scenario-based learning activities, which were discussed and refined until a draft dilemma in the form of a storyboard with audio and animated elements was agreed. Figure 11 shows a section of this draft storyboard.

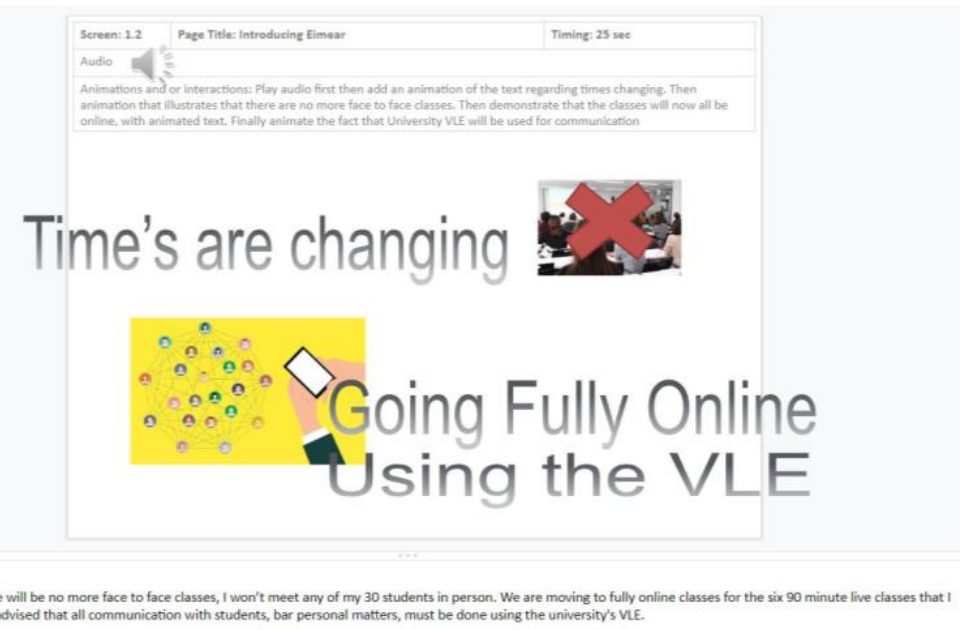

Figure 11. Section of the draft Eimear's dilemma storyboard

Step 3S: Prototype the scenario

The draft dilemma facilitated a discussion on how best to present the dilemma: either real-life or animation, with or without branching. Eventually, the constraints of the project dictated that an animated version without branching was the best option. A prototype was developed using VideoScribe (https://www.videoscribe.co/en), a video animator tool, along with what we named as takeaways: one-page documents that could be used to help solve the dilemma. These takeaways were developed using data generated from the literature review (Ní Shé et al., 2019) and examples of good online teaching practice suggested by the online educators, as evidenced in the empathy maps.

Step 4S: Review - Ideate and define

A comprehensive review of these materials was completed against the empathy maps, learning outcomes and curriculum design and discussed by the project team before agreement was reached on the final prototypes.

Step 5S: Final prototype

The final prototype, in video format, was created and made available for testing. The dilemma ended with a list of four possible actions that the participants were asked to select from (see Figure 12). The takeaway documents were available to inform participants of best practice in the area (see Figure 13).

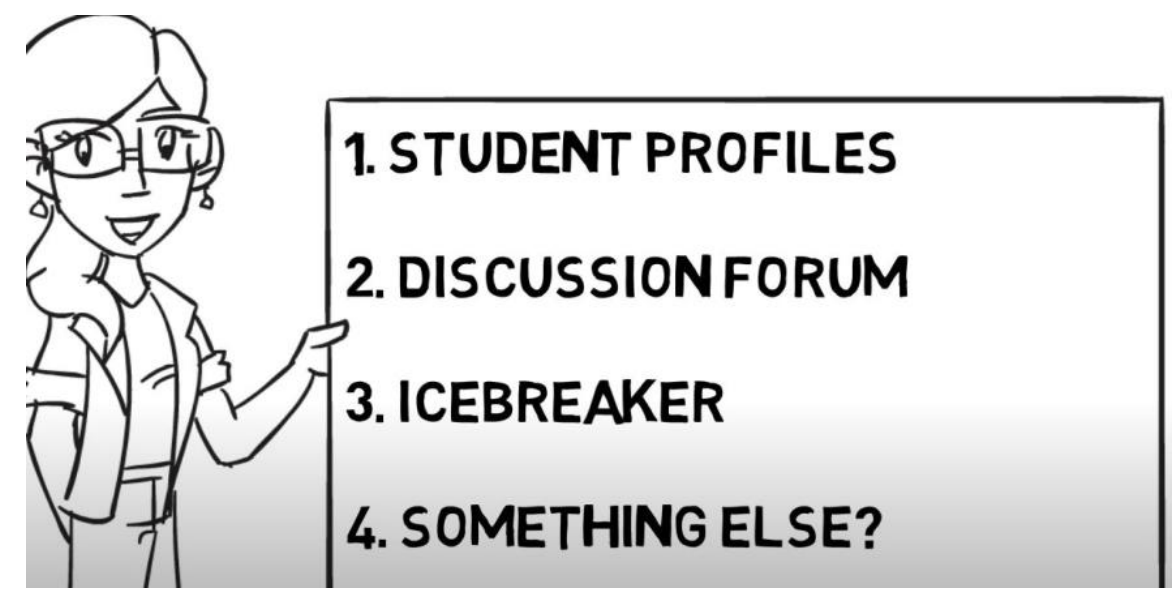

Figure 12. Visual excerpt from video created for Eimear's dilemma 
How can Social presence be achieved?

It is important to establish social presence at the beginning of the course and to maintain this presence throughout
the course. This can be achieved by you, the online educator, in several ways. Here are some best practice tips.

\begin{tabular}{|c|c|}
\hline Getting social presence off the ground & Maintaining Social presence \\
\hline $\begin{array}{l}\text { Post a short welcoming introduction video, audio or text that } \\
\text { includes a brief bio and a snippet of personal information. If using } \\
\text { text or audio, post a picture of yourself. }\end{array}$ & $\begin{array}{l}\text { Establish, and agree with your students, the response times for any } \\
\text { queries and/or postings, and stick to them. }\end{array}$ \\
\hline $\begin{array}{l}\text { Ask students to post a similar message about themselves and their } \\
\text { desires/expectations of the course. }\end{array}$ & \multirow{2}{*}{$\begin{array}{l}\text { Get to 'know' your students by listening to what they have to say } \\
\text { both in online classes and online interactions such as discussion } \\
\text { forums or emails. Get to know the names of the students and use } \\
\text { them in online classes. }\end{array}$} \\
\hline $\begin{array}{l}\text { Respond to the students initial posts as soon as is immediately } \\
\text { possible and include individualised feedback. Let them know you }\end{array}$ & \\
\hline $\begin{array}{l}\text { have read/listened to their post and that you care about them and } \\
\text { their requirements. }\end{array}$ & $\begin{array}{l}\text { Make sure your students get to 'know' you by responding to them } \\
\text { with individual personalised feedback that encourages them. }\end{array}$ \\
\hline $\begin{array}{l}\text { Run an icebreaker activity prior to the first teaching and learning } \\
\text { activity that will encourage student to student interaction, ensure } \\
\text { everyone gets involved. }\end{array}$ & $\begin{array}{l}\text { Regularly check if your students are on track and gently probe } \\
\text { those who are in difficulty. }\end{array}$ \\
\hline $\begin{array}{l}\text { Ask the students how they are getting on, have they found } \\
\text { everything and have they been able to figure out the technology }\end{array}$ & $\begin{array}{l}\text { Organise an online collaborative activity and engage with each } \\
\text { group, use verbal as well as textual communication. }\end{array}$ \\
\hline
\end{tabular}

Figure 13. Excerpt of the takeaway on social presence

\section{Workshops}

The workshops provided an opportunity to evaluate the prototype scenarios and associated course materials and provided the first juncture to examine the effectiveness of the design thinking process. Three workshops were held, ensuring all three dilemmas were tested at least once.

Testing the scenario and course materials

At the start of the workshop, the aim of the \#OpenTeach project was outlined. The attendees were then allocated into groups and given the following course materials:

- $\quad$ Persona in the form of a written document (like Figure 8 above)

- Dilemma, as a video, played on the screen in front of all participants - see the final version in YouTube (open teach, 2020)

- Document containing the text of the dilemma

- Exercise worksheet to solve the dilemma (Figure 14)

- Evaluation worksheet for feedback on workshop (Figure 15)

- $\quad$ Literature report (Ní Shé et al., 2019).

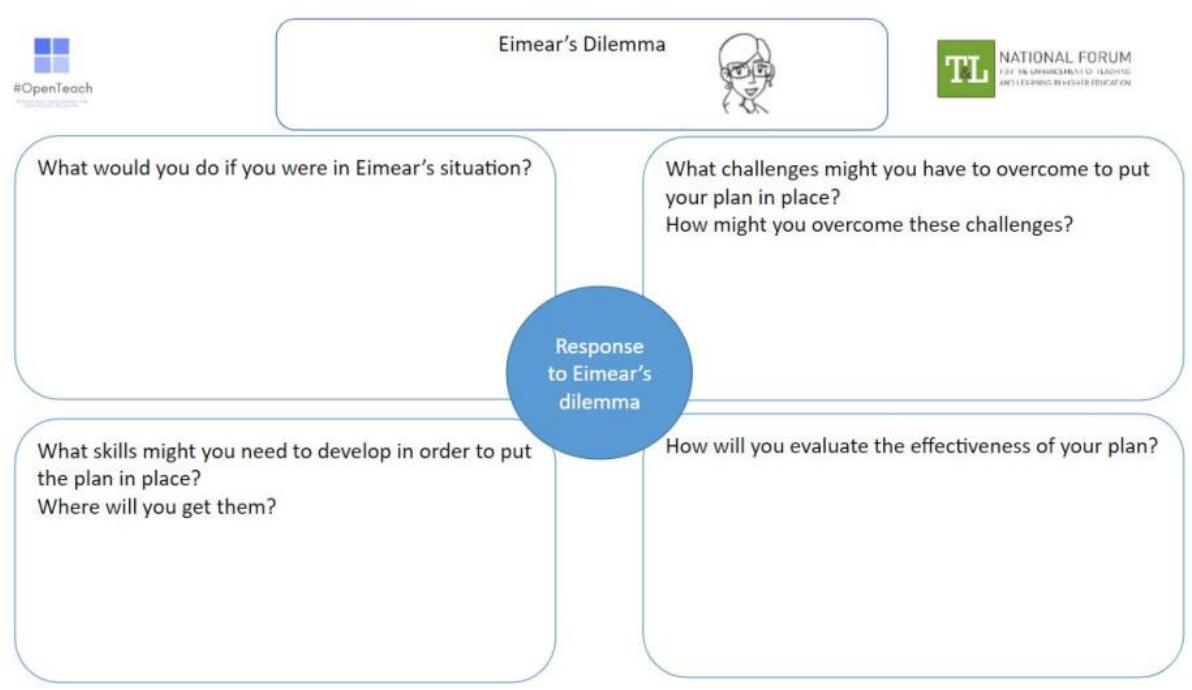

Figure 14. Response to Eimear's dilemma. This was completed by groups as a response to the dilemma played as a video in the workshop. 


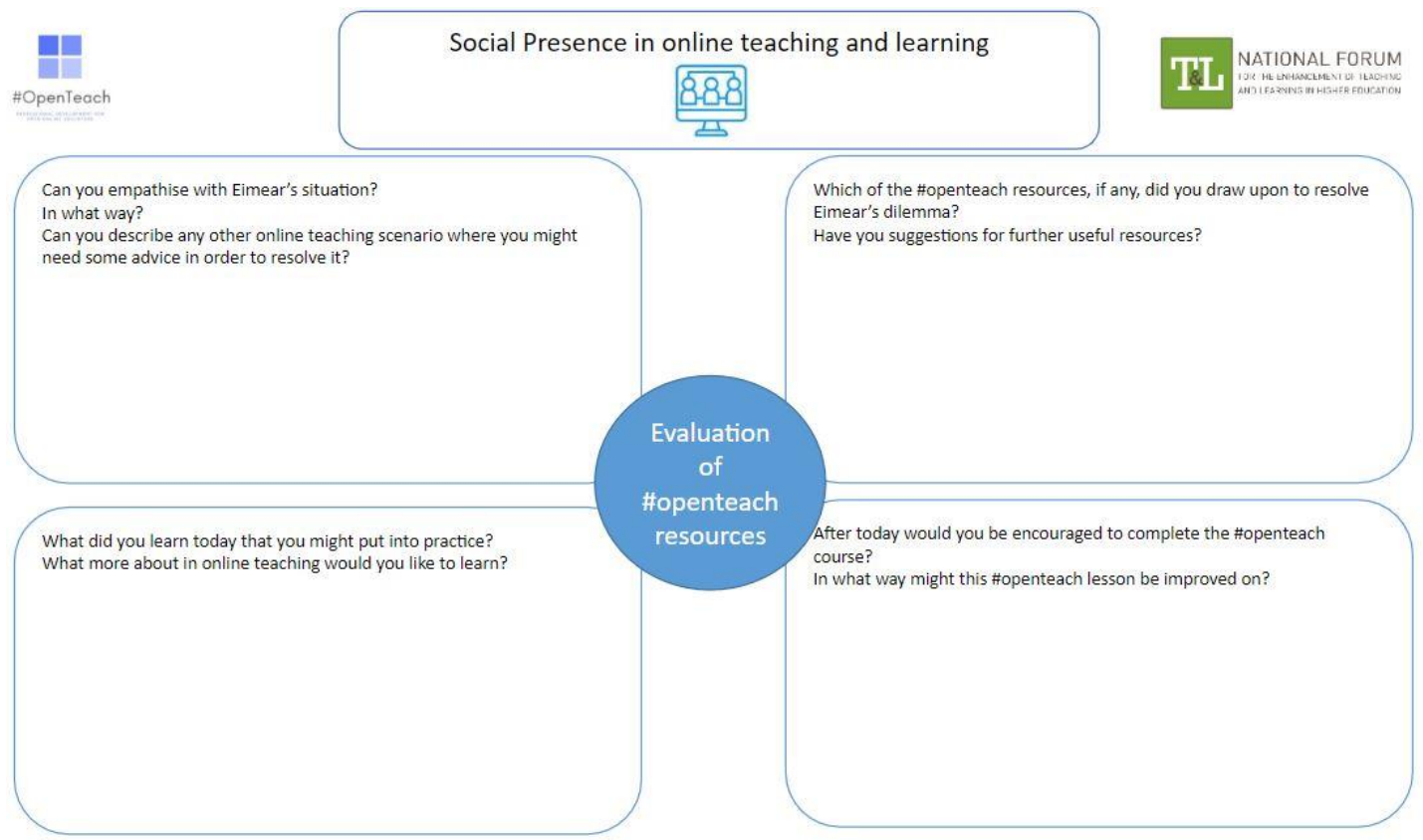

Figure 15. Evaluation of scenario workshop. This was completed individually by the participants.

Redefine, ideate, prototype

The workshop data was then used to inform modifications to the takeaway documents and the scenario. This resulted in a new version of course materials which were used and tested in subsequent workshops.

\section{Workshop data analysis}

To examine the impact design thinking had on the development of the course materials, participants were given an evaluation sheet to complete at the end of the workshop (see Figure 15). The questions asked in each quadrant were aimed at establishing what, if any, effect the design thinking process had on the user experiences, thus answering research question 2. For example, empathising with the user is core to design thinking; therefore, we wanted to establish if the persona we created for the scenario resonated with the participants, hence the question in the top-left quadrant; similarly for the resources referred to in the topright quadrant. One aim of the course was that participants would learn how to deal with such scenarios; the user's learning experience was addressed in the quadrant on bottom left. The question asked in the quadrant on the bottom right was aimed at finding out what might be missing from the course. Deductive direct content analysis, as described in the Methodology section, was used to analyse the workshop evaluation sheets data $(n=29)$, (see Figure 15, (e) in Table 2 ). The data was initially coded within a category representing each of the questions asked in the evaluation sheet (see Figure 15). Subcodes, such as for describing the type of information we sought, were then created. For example, the Positive_Empathy and Negative_Empathy codes contained the responses to the question in the first quadrant of Figure 15 "Can you empathise with Eimear's situation?", which indicated whether participants agreed or not with this statement. Once the individual questions were coded, we amalgamated similar codes across the different questions. For example, codes relating to requirements for further training were found in response to a number of the questions and were then coded together.

Figure 16 contains an excerpt from the NVivo codebook relating to the first question asked, with the number of responses coded to each code category. 


\begin{tabular}{|c|c|c|}
\hline Name & Description & $\begin{array}{l}\text { No. of } \\
\text { respondents }\end{array}$ \\
\hline A1_Empathise with Eimear & Can you empathise with Eimear's situation? In what way? & 29 \\
\hline Feedback difficulty & Empathise with the lack of feedback from students in online classes & 2 \\
\hline Isolation and Void & Empathetic to Eimear's sense of intimidation and isolation at the prospect of online & 4 \\
\hline Lack of time & Empathise with the last minute and lack of time nature of Eimear's situation & 4 \\
\hline Negative empathy & No, Participant was not empathetic to Eimear's Dilemma & 1 \\
\hline New to it & Empathetic to the fact that Eimear is new to online teaching and the associated issues & 14 \\
\hline Positive_Empathy & Yes, participant empathised with Eimear's dilemma & 27 \\
\hline Presence & Empathetic to Eimear's need to know students and establish a presence & 4 \\
\hline Somewhat_Empathetic & $\begin{array}{l}\text { The participant expressed some empathy to Eimear's dilemma, though was not wholly } \\
\text { empathetic }\end{array}$ & 4 \\
\hline $\begin{array}{l}\text { Training and or support and or } \\
\text { skills required }\end{array}$ & Empathetic to Eimear's need for training & 6 \\
\hline
\end{tabular}

Figure 16. Codebook sample from NVivo

This process was repeated for the remainder of the questions. The discussion below uses select data from this coding to illustrate the impact of the design thinking process.

In the following sections, the outcomes of the data analysis are presented in line with each of the quadrants presented in the evaluation sheet (see Figure 15).

\section{Empathy with end user}

The response to this was overwhelmingly positive: 27 of the 29 participants who responded agreed that they empathised with Eimear. Many of them $(n=14)$ were able to reflect on their own experiences of starting to teach online and expressed the isolation and fears they had. One participant said, "Moving to fully online can be daunting and can cause a "crisis" of confidence". Others had not yet taught online but were aware of such fears. One participant said, "We are starting to move some classes online and there is fear involved", while another who had not yet engaged in online learning stated, "Starting an online course would be the same for me as well (as for Eimear)". The issue of establishing presence was also to the fore, as one participant remarked, "Yes, fears about creating a meaningful presence and the how", and another stated that they "need to know your learners in advance". Another participant pointed to administrative problems with establishing this presence when she said, "Opening up communication with online students - often not enrolled in time". These responses reflect the issues that Eimear had encountered and expressed in the associated dilemma.

When asked about other scenarios where they might need advice, many participants $(n=12)$ suggested scenarios around student facilitation and engagement.

\section{Course materials}

Ten of the participants referred to having used the social presence takeaway in order to solve the dilemma. For example, one participant said, "The social presence document was very interesting and useful ... social media tools and their effective use". A number of the participants referred to how useful the list of prompts or nuggets in the takeaways were; for example, one participant said, "The grid at the bottom - quick guides which I could glance over every year" (see example in Figure 13). Others referred to the fact that they had discussed the solution themselves in their groups, with or without reference to the course materials. For example, one participant said, "mostly table discussion but points raised reflected nuggets in 'social presence' prompt sheet. Clearly, the takeaway document contained tips that the participants found useful as well as mirroring their own suggested solutions. 
There was a diverse range of suggestions for further useful resources relating to webinars, including Padlet and Twitter. One individual pointed to the need for a group agreement in such exercises, and another suggested a discussion on the fears associated with online teaching and learning.

\section{Learning}

Three main themes emerged from the responses to the question on what the participants learned. Firstly, many participants considered that they learned about the importance of incorporating online student orientation, with short introductory videos and icebreakers $(n=8)$. One participant suggested they would, "have an online session devoted to tech orientation and ice breaking activities at the start", and another pointed out the need for "better scaffolding and assistance for students with orientation/intro section to module". They equated this with the development of social presence: for example, one participant stated, "at the start more social presence activity required", and another stated, "beginning the process of creating an online presence that is meaningful and that will create a reason for students to engage".

The second theme was around the importance of engagement and encouraging discussions $(n=8)$. One participant said they learned the importance of "trying to encourage more online discussions as opposed to answering questions", and another established how to manage "discussion forum activity and types of engagement to support students in their learning".

The third theme concerned tools and strategies. Participants expressed the fact that they had learned effective strategies. For example, one participant wrote "blended approach - short video clips plus quizzes, questions and answers incorporated into the lecture", and another stated, "Delivery of content should be differentiated to keep students engaged".

The theme of tools was also dominant in the participants' requirements for what more they would like to learn $(n=6)$. For example, one participant said, "more practical workshops on some tools/systems that ... work for online learning".

\section{Attendance at future \#OpenTeach course}

Almost all the participants $(n=26)$ indicated that they would complete the \#OpenTeach course when it became available. There were a number of suggestions about how to improve the course such as withholding the takeaway documents until after the groups had put forward their response, mixing groups between different institutions and providing a "solution" to the dilemma and developing a forum for sharing practice. A number of the participants $(n=3)$ specifically mentioned the value of being an online student prior to teaching.

\section{Discussion}

This study set out to examine how design thinking can be successfully integrated into the ID process using a case study of the development of the \#OpenTeach course. We sought to describe the practical details of implementing the design thinking process, and the effects this had on the experiences of the participants in the first pilot workshop. In the next two subsections, the two research questions are addressed:

(1) How was design thinking integrated into the ID of the \#OpenTeach course?

(2) What was the effect of the design thinking process on the user experiences in the first pilot workshop of the course?

Reflections on the process, limitations and future work are then discussed prior to the conclusion and recommendations.

\section{Integration of design thinking in the ID process}

In answer to the first research question, the iterative and agile method of developing the course materials, as illustrated in Figure 2, demonstrates how design thinking was integrated into the \#OpenTeach course. There is evidence to suggest that instructional designers, involved in online learning, have difficulty with the process of empathising with their learners due to tensions such as settling on a methodology and dealing 
with multiple stakeholders and time or project constraints (Matthews et al., 2017). This study has demonstrated how a design thinking methodology can be used to ensure empathy with learners is established. Practitioners in the field can implement this methodology by following the detailed descriptions of persona and scenario development, as illustrated in Figures 3 and 9 respectively. The identification of key stakeholders ensured there were no conflicts in the understanding of the learner needs. The potential learners for the course, the OEU online educators and their students and managers, were consulted in the early stages of the process (see Figure 1). Once the prototype was tested in the workshops, further stakeholders in the form of the wider community of online educators were consulted. These practices are illustrative of how practitioners should, and can, engage effectively with stakeholders.

A key element of design thinking is to facilitate creativity and allow thinking "outside the box" (Dam \& Siang, 2020a). The innovative use of the personas as the scenario characters, as when the Aoibheann persona became the Eimear character in the first scenario, is an example of such creativity. Using the empathy maps as a starting point, the creatively designed takeaway documents (see Figure 14) contained prompts and short descriptions of tools and strategies that students can refer to. These are examples of effective instructional materials, developed from a design thinking methodology, which have been identified as a fundamental requirement of engaging the increasingly technology-equipped students (Conole, 2013; Goodyear, 2015; Laurillard, 2012; Svihla, 2017). In order to engage students, instructional designers should follow the creative process documented in this study, when designing instructional materials. Furthermore, they should use documents containing key advice on best practice, with examples as part of their takeaway material for online courses.

Finally, the workshop was used to test the prototype in order to evaluate "the conditions of use, how people think, behave, and feel, and to empathise" (Dam \& Siang, 2020a, Section 5). Some changes were made for the final course delivery, such as including webinars that allowed participants practise with technology tools, using cross-institutional groups for teamwork and providing suggested dilemma solutions based on responses from the course participants. These workshops proved invaluable to the success of the final design of the \#OpenTeach course. The use of such workshops by instructional designers allows consultation with key stakeholders within a predefined process and avoids some of the difficulties of time and project constraints that have been identified as barriers to successful empathy with learners (Matthews et al., 2017).

\section{Workshop - Pilot outcomes}

In answer to the second research question, almost all the participants who responded to the questionnaire identified with Eimear, expressing similar anxieties and lack of confidence. The empathy they expressed demonstrates how the course materials and content reflect the users: key principles in design thinking. In addition, many participants agreed with the need to get to know their learners in advance and establish an online presence right from the start: a key component of effective online teaching as identified in the literature review (Ní Shé et al., 2019). Participants found the takeaway document helpful, referencing the value of the nuggets of information provided, confirming our choice of such materials. One of the aims of the \#OpenTeach course was to encourage participants to explore how to engage students in online communication. Participants demonstrated they had learnt ways to facilitate engagement; many suggested they would use short online video introductions, icebreakers and a mix of strategies to engage students all of which have been identified as good practice (Ní Shé et al., 2019). One successful way for educators to learn how to facilitate online students is to become an online student themselves (Adnan \& Ritzhaupt, 2017) - a fact that participants referred to in the evaluations. The process used in this project demonstrates how instructional designers can effectively empathise with their learners and produce courses that meet their learners' needs as well as the course learning objectives.

\section{Reflections on our experiences}

According to Svihla (2017), the design thinking process is reflective of the iterative practices and inherent sensibilities of experienced instructional designers and is therefore sometimes implicit in an instructional designer's work. In agreement with Svihla, we found that aspects of the design thinking process fit with the practices we have as instructional designers. For example, the development of personas was not something new to us. However, the concentrated and iterative development of the empathy map using multiple sources of data was new. The attendance to user empathy throughout the design thinking stages and subsequent gathering of focused feedback during the pilots drew out aspects of the course that required change. It was 
this continuous return to the potential users that ensured a focus on user experience. This is the core of design thinking. Thus, the use of the design thinking process, as documented in this paper, may be used by instructional designers to overcome some of the barriers that have been identified in successfully empathising with learners (Matthews et al., 2017).

\section{Limitations and future research}

In this article, we have documented the use of design thinking and considered our reflections on the ID process. However, further comparison of the five stages of design thinking with common practices of instructional designers, needs to be undertaken in order to examine design thinking as a separate branch of ID (Svihla, 2017). In addition, the workload involved in analysing the data to the degree required for the design thinking process is immense. This tension, between empathising with the learner and attending to other ID tasks, has been identified in research (Matthews et al., 2017). Further research is needed to determine whether this time-consuming effort pays off and whether constraints, such as a necessity for a module to meet accreditation demands, can be accommodated using design thinking. Although this article reports on the use of design thinking in the development of one of the scenarios of the \#OpenTeach course, further workshops were carried out prior to the final delivery of the course. It is planned that the evaluation data available from these workshops, and the final course delivery, will be used to further validate the use of design thinking.

\section{Conclusions and recommendations}

Our immersion in the online educator data during the development of the persona and scenario ensured we were thinking as well as working the design thinking process (Dam \& Siang, 2020a). The feedback from the workshop validated the use of the Eimear persona and her dilemma. Eimear hooked our users in as they identified with her and therefore focused on how to overcome such a dilemma. The need for creative and iterative ways of developing course materials is not only rooted in design thinking but supports the calls from many educators as stated by Philip (2018, p.78) for "the development of student learning experiences (that) should be more design-based, that is, initiated and supported by a process of purposive design, which is creative and iterative". The use of the design thinking process in this project illustrates how a creative and iterative process may be used by instructional designers to achieve empathy with their learners, which will ensure learners successfully engage and achieve the learning objectives of the course. We recommend that instructional designers use the processes outlined in this paper to help them overcome some of the tensions that have identified in improving the learning environment for their learners (Matthews et al., 2017).

This article contributes to how design thinking can be effectively implemented within the ID processes, which has been identified as a gap in the literature both in ID methods (Christensen \& West, 2017; Matthews et al., 2017) and in the implementation of design thinking in education (Svihla, 2017). Finally, there is a recognition that new models of ID based on exemplary practice need to be mapped out (Christensen \& West, 2017; Conole, 2013; Dimitriadis \& Goodyear, 2013; Matthews et al., 2017; Philip, 2018; Wasson \& Kirschner, 2020). The documentation of this case study of design thinking is an important step in the construction of an account of a new ID model. This model should be implemented and further evaluated by instructional designers seeking to develop effective learning environments.

\section{Acknowledgements}

The \#OpenTeach project was funded by the National Forum for the Enhancement of Teaching and Learning in Ireland.

\section{References}

Adnan, N. H., \& Ritzhaupt, A. D. (2018). Software engineering design principles applied to instructional design: What can we learn from our sister discipline? TechTrends, 62(1), 77-94. https://doi.org/10.1007/s11528-017-0238-5

Bates, A. W. (2019). Teaching in a digital age (2nd ed.). Tony Bates Associates Ltd. https://pressbooks.bccampus.ca/teachinginadigitalagev2/ 
Branch, R. M., \& Kopcha, T. J. (2014). Instructional design models. In J. Spector, M. D. Merrill, J. Elen, \& M. J. Bishop (Eds.), Handbook of research on educational communications and technology (4th ed., pp. 77-87). Springer. https://doi.org/10.1007/978-1-4614-3185-5_7

Brenner W., Uebernickel F., \& Abrell T. (2016). Design thinking as mindset, process, and toolbox. In W. Brenner \& F. Uebernickel (Eds.), Design thinking for innovation (1st ed., pp. 3-21). Springer https://doi.org/10.1007/978-3-319-26100-3_1

Christensen, K., \& West, R. E. (2017). The development of design-based research. In R. E. West (Ed.), Foundations of learning and instructional design technology. EdTech Books. https://edtechbooks.org/lidtfoundations/development_of_design-based_research

Conole, G. (2013). Designing for learning in an open world (Vol. 4). In J. M. Spector \& S. LaJoie (Eds.), Explorations in the learning sciences, instructional systems and performance technologies. Springer. https://doi.org/10.1007/978-1-4419-8517-0

Dam, R. F., \& Siang, T. Y. (2020a). 5 Stages in the design thinking process. Interaction Design Foundation. https://www.interaction-design.org/literature/article/5-stages-in-the-design-thinkingprocess

Dam, R. F., \& Siang, T. Y. (2020b). Design thinking: Get a quick overview of the history. Interaction Design Foundation. https://www.interaction-design.org/literature/article/design-thinking-get-a-quickoverview-of-the-history

Dam, R. F., \& Siang, T. Y. (2020c). Personas - A simple introduction. Interaction Design Foundation. https://www.interaction-design.org/literature/article/personas-why-and-how-you-should-use-them

Dimitriadis, Y., \& Goodyear, P. (2013). Forward-oriented design for learning: Illustrating the approach. Research in Learning Technology, 21, 1-13. https://doi.org/10.3402/rlt.v21i0.20290

Elo, S., \& Kyngäs, H. (2008). The qualitative content analysis process. Journal of Advanced Nursing, 62(1), 107-115. https://doi.org/10.1111/j.1365-2648.2007.04569.x

Farrell, O., Brunton, J., Costello, E., Ní Shé, C., Donlon, E., Trevaskis, S., \& Eccles, S. (2019). An investigation of effective online teaching: A needs analysis of online educators and online students. Zenodo. https://doi.org/10.5281/zenodo.3929199

Gibbons, S. (2016). Design thinking 101. Nielsen Norman Group. https://www.nngroup.com/articles/design-thinking/

Gibbons, S. (2018). Empathy mapping: The first step in design thinking. Neilson Norman Group. https://www.nngroup.com/articles/empathy-mapping/

Göksu, I., Özcan, K. V., Cakir, R., \& Göktas, Y. (2017). Content analysis of research trends in instructional design models: 1999-2014. Journal of Learning Design, 10(2), 85-109. https://doi.org/10.5204/jld.v10i2.288

Goodyear, P. (2015). Teaching as design. HERDSA Review of Higher Education, 2(2), 27-50. http://www.herdsa.org.au/wp-content/uploads/HERDSARHE2015v02p27.pdf

Harley, A. (2015). Personas make users memorable for product team members. Nielsen Norman Group. https://www.nngroup.com/articles/persona/

Kahu, E. R. (2013). Framing student engagement in higher education. Studies in Higher Education, 38(5), 758-773. https://doi.org/10.1080/03075079.2011.598505

Laurillard, D. (2012). Teaching as a design science: Building pedagogical patterns for learning and technology. Routledge. https://doi.org/10.4324/9780203125083

Liedtka, J. (2017). Evaluating the impact of design thinking in action. Academy of Management Proceedings, 1, 10264-10270. https://doi.org/10.5465/AMBPP.2017.177

Luka, I. (2014). Design thinking in pedagogy. Journal of Education Culture and Society, 5(2), 63-74. https://doi.org/10.15503/jecs20142.63.74

Matthews, M. T., Williams, G. S., Yanchar, S. C., \& McDonald, J. K. (2017). Empathy in distance learning design practice. TechTrends, 61(5), 486-493. https://doi.org/10.1007/s11528-017-0212-2

Morris, H., \& Warman, G. (2015). Using design thinking in higher education. EDUCAUSE. https://er.educause.edu/articles/2015/1/using-design-thinking-in-higher-education

Ní Shé, C., Farrell, O., Brunton, J., Costello, E., Donlon, E., Trevaskis, S., Eccles, S. (2019). Teaching online is different: Critical perspectives from the literature. Zenodo. https://doi.org/10.5281/zenodo.3479402

Ní Shé, C., Farrell, O., Bruton, J., Costello, E., Trevaskis, S., Donlon, E., \& Eccles, S. (2020, April 30). DCU case study: Using ABC to design an online teaching course for open online educators. $A B C$ Learning Design. https://abc-ld.org/casestudy/dcu-case-study2/

open teach. (2020, March 25). Unit 2: Eimear's dilemma [Video]. YouTube. https://www.youtube.com/watch?v=qb9FDPilPZI 
Philip, R. (2018). Finding creative processes in learning design patterns. Australasian Journal of Educational Technology, 34(2), 78-94. https://doi.org/10.14742/ajet.3787

Silverman, D. (1993). Interpreting qualitative data. Sage.

Smith, P. L., \& Ragan, T. J. (2005). Instructional design (3rd ed.). Wiley \& Sons.

Stake, R. E. (1995). The art of case study research. Sage.

Stefaniak, J. (2020). The utility of design thinking to promote systemic instructional design practices in the workplace. TechTrends, 64(2), 202-210. https://doi.org/10.1007/s11528-019-00453-8

Svihla, V. (2017). Design thinking and agile design: New trends or just good designs? In R. E. West (Ed.), Foundations of learning and instructional design technology. EdTech Books. https://edtechbooks.org/lidtfoundations/design thinking_and agile_design

Tawfik, A. A., Gatewood, J., Gish-Lieberman, J. J., \& Hampton, A. J. (2021). Toward a definition of learning experience design. Technology, Knowledge and Learning, 2021, 1-26. https://doi.org/10.1007/s10758-020-09482-2

Wasson, B., \& Kirschner, P. A. (2020). Learning design: European approaches. TechTrends, 64(6), 815827. https://doi.org/10.1007/s11528-020-00498-0

Yin, R. K. (2003). Case study research: Design and methods (3rd ed.). Sage.

Young, C., \& Perović, N. (2016). Rapid and creative course design: As easy as ABC? Procedia - Social and Behavioral Sciences, 228, 390-395. https://doi.org/10.1016/j.sbspro.2016.07.058

Corresponding author: Caitríona Ní Shé, caitriona.nishe@tcd.ie

Copyright: Articles published in the Australasian Journal of Educational Technology (AJET) are available under Creative Commons Attribution Non-Commercial No Derivatives Licence (CC BY-NC-ND 4.0). Authors retain copyright in their work and grant AJET right of first publication under CC BY-NC-ND 4.0.

Please cite as: Ní Shé, C., Farrell, O., Brunton, J., \& Costello, E. (2022). Integrating design thinking into instructional design: The \#OpenTeach case study. Australasian Journal of Educational Technology, 38(1), 33-52. https://doi.org/10.14742/ajet.6667 